高齢者に発見された胸腺原発 MALT リンパ腫の1例

畑中克元 1 - 安達勝利 1

要旨一一背景 . 胸腺原発リンパ腫は非常に稀な節外性リンパ腫で, 前縦隔に大きな不整形腫瘤を形成し, 胸腺腫, 胚 細胞性腫瘍等, 乥の他の縦隔腫痬との鑑別が問題となることが多い. 症例.82 歳, 男性 .急性気管支炎にて当院内科入 院中, 胸部 CT で前縦隔に大きな辺縁平滑な腫瘤を指摘された . 胸腺腫の疑いで当科入紹介となり，胸骨正中切開，前 縦隔腫瘍亜全摘術を施行，胸腺原発MALT リンパ腫と診断された . 結論 . 非常に稀な胸腺原発 MALT リンパ腫の 1 例 を経験し，胸腺腫との鑑別に免疫組織化学染色が有用であったので報告した．(肺癌．2005;45:351-355)

索引用語——縦隔悪性リンパ腫，粘膜関連リンパ組織，胸腺

\title{
A C ase of Mucosa-associated Lymphoid Tissue (MALT) Lymphoma of the Thymus in an Octogenarian
}

\author{
Katsumoto Hatanaka1; Katsutoshi Adachi ${ }^{1}$
}

\begin{abstract}
Background. Mucosa-associated lymphoid tissue (MALT) lymphoma of the thymus is a very rare extranodal malignant lymphoma. MALT Iymphoma of the thymus shows a large irregular mass in the anterior mediastinum on chest roentgenograms or CT scans. Therefore, differentiating MALT Iymphoma from other anterior mediastinal tumors, such as thymoma, or germ cell tumor, is difficult. Case. An 82-year-old man was admitted to the Internal Medicine Department of our hospital for treatment of acute bronchitis, whereupon chest X-ray film and CT showed a large, well-defined mass in the anterior mediastinum. Suspected of having thymoma, he was referred to our department for surgery. An anterior mediastinal tumor was removed through a standard midline sternotomy incision. As a result, the case was diagnosed as having MALT Iymphoma of the thymus. Conclusion. We described a case of MALT lymphoma of the thymus. Immunostaining of lymphocytes was useful in making an accurate diagnosis. (J J LC. 2005;45:351-355)
\end{abstract}

KE Y WORDS — Malignant lymphoma in the mediastinum, Mucosa-associated lymphoid tissue (MALT), Thymus

はじめに

縦隔に発生する悪性リンパ腫は, リンパ節の系統的罹 患の分症としてみられるものと 縦隔に原発するもの(節 外性リンパ腫)に分けられ ,Hodgkin 病の頻度が高い.胸 腺原発で, 特に粘膜関連リンパ組織に発生するMALT リンパ腫は非常に稀とされる . 最近われわれは，急性気 管支炎にて入院治療中, 偶然,胸部 CT で発見された胸腺 原発 MALT リンパ腫の 1 例を経験したので報告する .
症 例

症例：82 歳, 男性.

主訴：上縦隔異常陰影.

家族歴 : 特記事項なし。

既往歴：30 歳代, 虫垂切除術, 両側肋骨骨折, 80 歳, 白内障手術。

喫煙歴: 10 本/日× 60 年.

現病歴 : 2002 年 8 月 9 日, 夜間の強い咳嗽, 黄色の膿
1 新宮市立医療センター呼吸器外科・心藏血管外科 .

別刷請求先 : 畑中克元, 新宮市立医療センター呼吸器外科・ 心藏 血管外科, ₹ 647-0072 和歌山県新宮市蜂伏 18-7.

1Department of Thoracic and Cardiovascular Surgery, Shingu Municipal Center, Japan.
Reprints: Katsumoto Hatanaka, Department of thoracic and Cardiovascular Surgery, Shingu Municipal Medical Center, 18-7 Hachibuse, Shingu-shi, Wakayama 647-0072, J apan.

Received August 30, 2004; accepted April 21, 2005.

(C) 2005 The J apan Lung Cancer Society 
Table 1. Laboratory Data on Admission

\begin{tabular}{|c|c|c|c|}
\hline \multirow{2}{*}{$\begin{array}{l}\text { Peripheral blood } \\
\text { WBC }\end{array}$} & \multicolumn{2}{|r|}{ Blood chemistory } & \multirow[b]{2}{*}{$8.3 \mathrm{~g} / \mathrm{dl}$} \\
\hline & $3300 / \mu 1$ & TP & \\
\hline $\mathrm{RBC}$ & $371 \times 10^{4} / \mu 1$ & Alb & $3.3 \mathrm{~g} / \mathrm{dl}$ \\
\hline $\mathrm{Hb}$ & $11.5 \mathrm{~g} / \mathrm{dl}$ & T.Bil. & $3.15 \mathrm{mg} / \mathrm{dl}$ \\
\hline $\mathrm{Ht}$ & $35.3 \%$ & D.Bil. & $0.13 \mathrm{mg} / \mathrm{dl}$ \\
\hline Plt. & $23.3 \times 10^{4} / \mu 1$ & GOT & $13 \mathrm{IU} / \mathrm{I}$ \\
\hline CRP & $0.10 \mathrm{mg} / \mathrm{dl}$ & GPT & $12 \mathrm{IU} / \mathrm{I}$ \\
\hline \multirow[t]{2}{*}{ ESR } & $117 \mathrm{~mm} / \mathrm{hr}$ & $\gamma-\mathrm{GTP}$ & $47 \mathrm{IU} / \mathrm{I}$ \\
\hline & & $\mathrm{CHE}$ & $3.68 \mathrm{IU} / \mathrm{ml}$ \\
\hline Tumor markers & & ALP & 204 IU/I \\
\hline CEA & $2.6 \mathrm{ng} / \mathrm{ml}$ & LDH & $135 \mathrm{IU} / \mathrm{I}$ \\
\hline SLX & $46 \mathrm{U} / \mathrm{ml}$ & GLU & $85 \mathrm{mg} / \mathrm{dl}$ \\
\hline $\mathrm{SCC}$ & $<0.5 \mathrm{ng} / \mathrm{ml}$ & BUN & $9.3 \mathrm{mg} / \mathrm{dl}$ \\
\hline CYFRA & $<1.0 \mathrm{ng} / \mathrm{ml}$ & Cre & $0.69 \mathrm{mg} / \mathrm{dl}$ \\
\hline Pro-GRP & $17.6 \mathrm{pg} / \mathrm{ml}$ & $\mathrm{Na}$ & $142.5 \mathrm{mE} \mathrm{q} / \mathrm{l}$ \\
\hline NSE & $4.8 \mathrm{ng} / \mathrm{ml}$ & $\mathrm{K}$ & $4.1 \mathrm{mEq} / \mathrm{l}$ \\
\hline HCG- $\beta$ & $<0.2 \mathrm{ng} / \mathrm{ml}$ & $\mathrm{Cl}$ & $103.4 \mathrm{mE} \mathrm{q} / \mathrm{l}$ \\
\hline AFP & $3.25 \mathrm{ng} / \mathrm{ml}$ & $\mathrm{Ca}$ & $8.8 \mathrm{mg} / \mathrm{dl}$ \\
\hline \multirow[t]{2}{*}{ CA19-9 } & $10.64 \mathrm{U} / \mathrm{ml}$ & UA & $5.7 \mathrm{mg} / \mathrm{dl}$ \\
\hline & & CPK & $40 \mathrm{IU} / \mathrm{I}$ \\
\hline Arterial bood gas analysis & & T-Cho & $144 \mathrm{mg} / \mathrm{dl}$ \\
\hline $\mathrm{pH}$ & 7.451 & albumin/globulin ratio (A/G ratio) & 0.79 \\
\hline $\mathrm{PaCO}_{2}$ & $40.9 \mathrm{mmHg}$ & anti-nuclear antibody & $(-)$ \\
\hline $\mathrm{PaO}_{2}$ & $76.5 \mathrm{mmHg}$ & anti-DNA antibody & $(-)$ \\
\hline $\mathrm{HCO}_{3}^{-}$ & $27.9 \mathrm{mmol} / \mathrm{l}$ & anti-RNP antibody & $(-)$ \\
\hline$B E$ & $3.6 \mathrm{mmol} / \mathrm{l}$ & rheumatoid factor & $<5 \mathrm{U} / \mathrm{ml}$ \\
\hline $\mathrm{SaO}_{2}$ & $95.8 \%$ & & \\
\hline
\end{tabular}

性痰，発熱が出現し，近医を受診した．抗生斉の投薬を 受けたが, 症状軽快せず，軽度の黄疸も認めたため，8 月 14 日,当院内科入紹介となった .喀痰培養で, 肺炎球 菌，インフルエンザ桿菌が証明され急性気管支炎の診断 で, マクロライド系，ペニシリン系抗生剂の内服，およ び点滴にて解熱し, 症状も軽快したが, 入院時胸部 CT で前縦隔腫瘍を指摘された . 10 月 3 日，手術目的にて当 科入院となった。

入院時現症：身長 $165 \mathrm{~cm}$, 体重 $60 \mathrm{~kg}$, 血圧142/80 $\mathrm{mmHg}$,体温 $36.3^{\circ} \mathrm{C}$.表在リンパ節：触知せず.胸部：呼 吸音清，心杂隹音聴取せず．腹部：平坦，軟 .

Performance Status : Grade 1 .

入院時検査所見：血液生化学検査では白血球数 3300/ $\mu \mathrm{l}$, 分画で好中球数は $40.7 \%, \mathrm{CRP} 0.10 \mathrm{mg} / \mathrm{dl}$ と急性炎 症は正常化していたが, 血沈 $117 \mathrm{~mm}$ (1 時間值) と上昇 していた . また , T-Bil $3.46 \mathrm{mg} / \mathrm{dl}$ (直接ビリルビン/間接 ビリルビン比 $=0.17 / 3.29)$ と高非抱合型ビリルビン血症 を認めるも，光れ以外の肝機能はほぼ正常であった . TP $8.4 \mathrm{~g} / \mathrm{dl}$, Alb $3.7 \mathrm{~g} / \mathrm{dl}$, A/G 比 0.79 で, 高グロブリン血 症を認めた .腫瘍マーカーでは SLX が $46 \mathrm{U} / \mathrm{ml}$ と上昇し ていた (Table 1$)$.
胸部 X 線 (Figure 1A ) : 両肺野に浸潤影は認めなかっ たが，上縦隔の拡大を認めた．

胸部 CT (F igure 1B，1C) ：前縦隔に大きな腫瘤を認め る . 辺縁は平滑で，内部濃度は均一である .

以上の所見より非浸潤性胸腺腫と診断し，10月 8 日， 手術を施行した .

手術所見：胸骨正中切開にて縦隔腫瘍の摘出を行っ た．腫瘍は胸骨直下，心基部側に存在し，びまん性弾性 硬, 血管増生を伴っていた . 心囊, 左右縦隔胸膜と強固 に癒着しており, 左右横隔神経への浸潤が疑われたが， 左無名静脈, 主肺動脈とは剥離可能であった，下端より 頭側入剥離してゆき,一部心囊も含め縦隔腫瘍亜全摘出 を行った .なお, 左右横隔神経は温存した .

病理所見 (Figure 2A，2B，2C)：摘出標本はびまん性 に増生した胸腺で, 10×10×3.0 cm, 重量 $313 \mathrm{~g}$. 組織学 的には小型で異型の弱い細胞質淡明な細胞, すなわち中 心細胞樣細胞 (centrocyte-like cells; CCLs) のびまん性増 生がみられ，所々，形質細胞の集簇，増生もみられた . 胸腺上皮はほとんどみられず, 腫瘤周囲では同樣の細胞 の脂肪結合組織への浸潤がみられた . 免疫組織化学検査 の結果，増生した CCL 細胞，および淡明細胞はCD20 

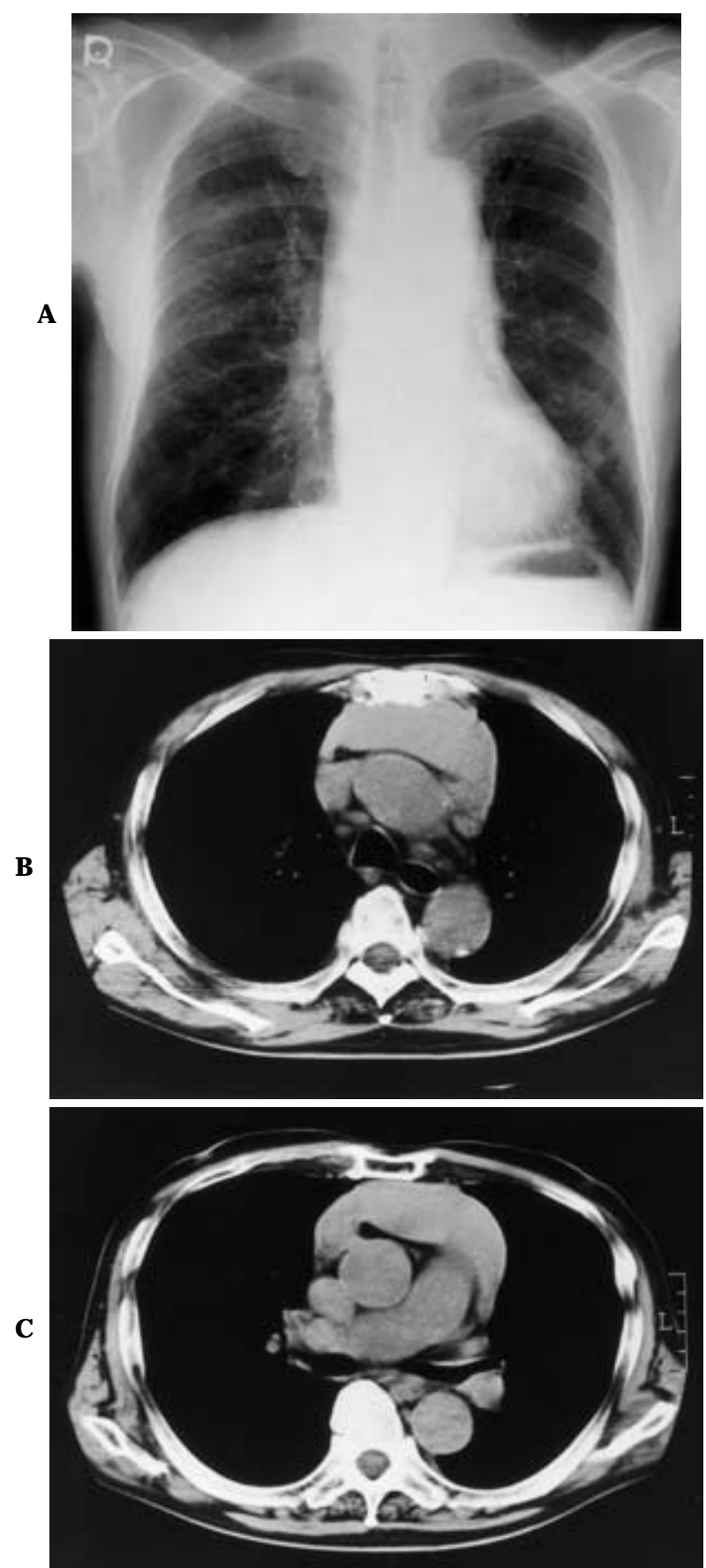

Figure 1. Chest X-ray film (A) on admission, showing a large anterior mediastinal mass shadow. Chest $\mathrm{CT}$ revealed the mass to be a homogeneous tumor. The boundary of the tumor being distinct at the aorto-pulmonary window level (B) and the pulmonary trunk level (C).

陽性で，CCL 細胞がケラチン (keratin) 蛋白染色で強く 染まった胸腺上皮へ浸潤 (lympho-epithelial lesion; LEL L) , 同部位でのケラチン染色の減弱を認めた . 周囲 では CD5，CD45RO 陽性 T細胞の集簇がみられたこと
A

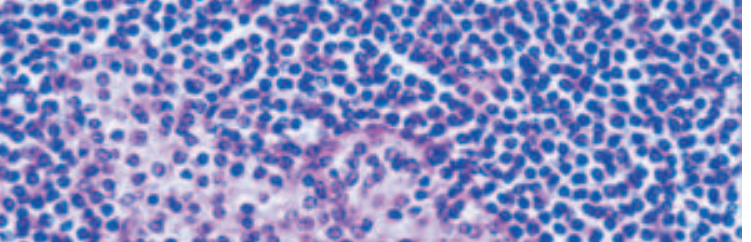

B
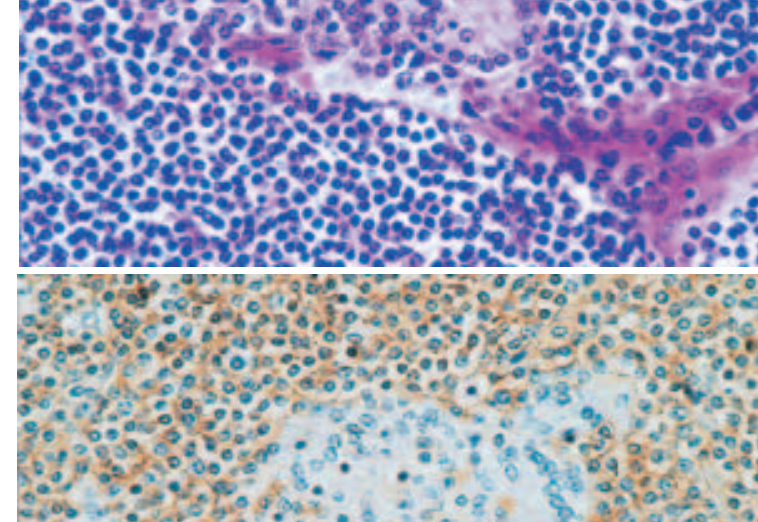

C
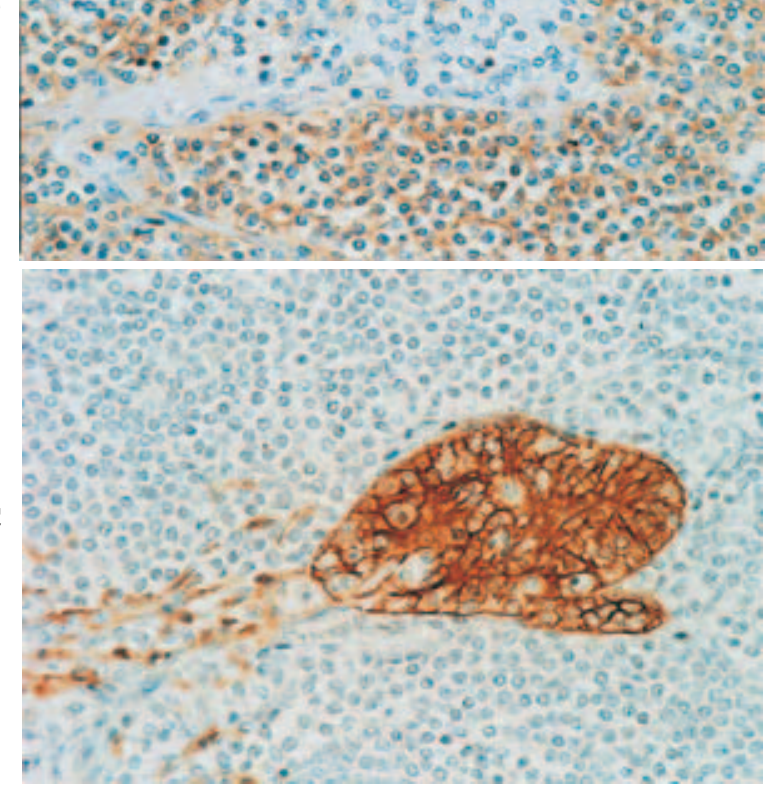

Figure 2. Pathological findings of the resected specimen. HE stain shows many small round cells of lowgrade malignancy and centrocyte-like cells. CCLs proliferating with some plasma cells. Some CCLs penetrate into the epithelium to form a lympho-epithelial lesion (A). The cytoplasms of tumor cells were immunohistochemically stained with CD20 (B). The epithelial cells of the thymus were strongly positive for keratin but the staining of the lympho-epithelial lesion was light (C).

より，胸腺原発MALT リンパ腫と診断された .なお，切 除した腫瘍の断端は左右横隔神経近縁等, 一部で陽性で あった .

術後経過：経過は概ね良好で術後 14 日目に血液内科 へ転科した . 同科にて骨髄生検を含む全身検索を受けた 
結果，骨髄への腫瘍細胞の浸潤はみられず，骨髄液の染 色体検査でも異常は認められなかった . 臨床病期分類 Stage IIA と判定され，化学療法 THP-COP (THP; pirarubicin , VCR; vincristin , CPA; cyclophosphamide , PSL; prednisolone)を開始し，3コースが予定されたが，肺炎 の併発のため 2 コースで中止された . 兴の後，放射線治 療を開始し，合計予定線量 $30 \mathrm{~Gy}$ であったが, , 白血球減少 による肺炎の併発，発熱持続等の有害事象が出現し，高 齢のため, $10.8 \mathrm{~Gy}$ で中止された . 現在, 術後 2 年余り経 過したが，再発なく，内科外来に通院中である。

\section{考 察}

MALT リンパ 腫 (malignant lymphoma of mucosaassociated lymphoid tissue) は，1983 年にIsaacson ら 1 により提唱された概念で , 粘膜関連リンパ装置(MALT) のリンパ濾胞の marginal zone の B リンパ球が腫瘍化し た低悪性度のリンパ腫で, リンパ組織腫瘍のREAL 分類 では節外性 (extranodal) の“ marginal zone B-cell lymphoma” と同義に取り扱われている.節外性リンパ腫( extranodal lymphoma)の好発部位は Waldeyer 輪，胃腸管 皮膚, 肺, 甲状腺, 唾液腺, 眼窝で, 最近は乳腺, 胆囊, 膀胱，腎孟なども報告されている 2,3 節外性リンパ腫の 発生には橋本病, シェーグレン症候群, 慢性関節リウマ チ, MCTD (mixed connective tissue disease) 等の自己免 疫機序やへリコバクター胃炎などの感染といった慢性炎 症過程が必須条件とされる 4.5 MALT リンパ腫の発生機 序としては，抗原刺激によりリンパ球に持続的な増殖シ グナルが入り，腫瘍化してくると考えられており，慢性 炎症を発生母地とすることが多い, 1,3,6,7 胸腺 MALT リ ンパ腫の 15 例を検討した稲垣らによると縦隔原発の悪 性リンパ腫は相対的に稀で, 弚の内訳では Hodgkin リン 八゚腫，原発性縦隔大細胞型 B 細胞性リンパ腫，小児リン パ芽球型リンパ腫で大半を占められ，稀に，低悪性度辺 縁帯 B 細胞性リンパ腫が存在するとされる 8.9 本疾患 に関する症例報告は非常に稀で，これまでわれわれの検 索し得た限り，自験例を含め 27 例にすぎない.稲垣らの 集計によると臨床的特徵としては, アジア人に多いとさ れ, 発症年齢は 36〜75 歳 (平均 55 歳), 性差は $1: 4$ と 女性に多く，10 例 (66.7\%) は無症状で，スクリーニン グ検査により前縦隔腫瘤を指摘されており，11 例 (73.3\%) でSjögren 症候群 (8 例) を始めとした自己免疫 疾患との関連が認められている? 病理学的特徵として 辺縁帯 (マントル層外層) の $\mathrm{B}$ リンハ球由来が強く推測 され，中心細胞樣細胞 (centrocyte-like cells; CCLs) とい われる腫瘍性 B 細胞集団に取り囲まれた反応性胚中心 の形態をとり，ときに形質細胞への分化を示す．また腫 瘍細胞か溉存の上皮細胞や腺管内に浸潤し，リンパー上
皮巣 (lympho-epithelial lesion; LEL) を形成する.免疫組 織学的にCD20(+), CD5 (-), CD10 (-), slgD (-) を示す. 予後は比較的良好で, 腫瘍は発生藏器に限局す る傾向を示し，10 年生存率で約 $80 \%$ である.NonHodgkin リンパ腫の治療法については低悪性度の場合 ,I 期，II 期では放射線治療が主体であるが,III 期，IV 期で は確立した治療法はなく，強力な化学療法を行っても長 期予後は必ずしもよくならないため経過観察することが 多い. 高悪性度群にはCHOP (cyclophosphamide， hydrochloro-doxorubicin, oncovin, prednisolone) 等, 強力な多阂併用化学療法か試みられている．本疾患の場 合まだ症例数が少ないことから確立した治療法はなく， 現実的には手術による摘出や放射線療法が主体となって いる.なお，本疾患は低悪性度であるが，高悪性度 MALT リンパ腫へ転化し得るとされている．本症例の場合，術 前の胸部単純 CT では, 胸骨直下に前縦隔ほぼ全体を占 拠する腫瘤を認め, 辺縁は平滑で内部濃度は均一であっ た . 近接大血管の変形等はみられず, 非浸潤性胸腺腫が 最も疑われた.組織診断を得る手段として，CT ガイド下 経皮針生検と診断的手術が考えられたが，腫瘍容積が大 きく, 将来, 周囲臓器への圧迫を来すお光れもあったた め,外科的腫瘤切除を選択した。なお，CT ガイド下経皮 針生検により組織診断が得られた場合，手術は行わず， 化学療法，放射線療法が選択された可能性がある．年齢 では 82 歳と報告中, 最高齢で, 軽度黄疸を伴う高非抱合 型ビリルビン血症の合併をみたが, 肝炎ウイルスマー カー，各種自己抗体とも陰性であった(Table 1) . 高グロ ブリン血症, 赤沈 $117 \mathrm{~mm}$ (1 時間值)と異常高值を認め, 胸腺 $\mathrm{B}$ リンパ球に対する何らかの慢性炎症があったと 考えられる なお，胃生検ではリンパ腫やへリコバクター 胃炎は証明されなかった．また，造血器腫瘍のマーカー として可溶性インターロイキンー2 受容体 (soluble interleukin-2 receptor)があり, 非 Hodgkin リンパ腫で著 明な高值を示し, 病勢の推移をよく反映して変動するこ とから, 治療中のモニタリング, 寛解後の再発予知の優 れた指標とされる . 本症例においては術後約 2 年余り経 過したが, 最近の内科外来における本症例の血清 SIL-2R では, 825〜1160 U $/ \mathrm{ml}$ 前後で推移し, 大きな変動はみら れていない，本リンパ腫の組織診断には形態学的特徵に 加え,リンハ球表面マーカー, cytokeratin, 免疫グロブリ ン軽鎖などの免疫組織化学染色が必要で，これまで慢性 炎症を伴った胸腺囊胞やリンパ球優性型胸腺腫と診断さ れていた症例のなかに胸腺 MALT リンパ腫がまぎれこ んでいる可能性があり, 8 今後, 症例数の増加も予想され る.胸腺 MALT リンパ腫に関与する遺伝子異常の研究や 有効な゙治療戦略の確立等, さらなる症例の蓄積が望まれ る。 
まとめ

他病治療中，偶然発見された高齢者の胸腺原発 MALT

リンパ腫の 1 例を経験し，確定診断において，リンパ球

表面マーカーなどの免疫染色が有用であった .

\section{REFERE NCES}

1. Isaacson PG, Chan JK, Tang C, et al. Low-grade B-cell lymphoma of mucosa-associated lymphoid tissue arising in the thymus. AmJ Surg Pathol. 1990;14:342-351.

2 . 宮原佐弥, 吉田進，木村正樹，他 .粘膜関連リンパ組織 (MALT) リンパ腫の 2 切除例 . 竹田綜合病院医学杂隹誌 . 2002;28:39-42.

3 . 岡部光邦, 稲垣 宏, 栄本忠昭. 腎孟に発生したMALT Iymphoma の 1 例 . 日本病理学会会誌 . 2001;90:267.

4 . 伊勢美樹子, 半沢多恵子, 堺田恵美子, 他 .胸腺に原発し,
骨髄浸潤やＭ蛋白血症を伴った MALT リンパ腫の一例 . 臨床血液 . 2000;41:1058.

5 . 山本 聡, 向井正也, 後藤明子, 他.MCTDに合併した胸 腺原発 MALT リンパ腫により胸腺に血球貪食像を認め 血球减少をきたした一例．臨床血液．2003;43:391.

6 . 林雄一郎, 酒井 優, 松熊晋, 他.耳下腺及び胸腺に発 生したMALT リンパ腫と考えられた 1 例 . 日本病理学会 会誌. 2001;90:267.

7 . Takagi N, Nakamura S, Yamamoto K, et al. Malignant lymphoma of mucosa-associated lymphoid tissue arising in the thymus of a patient with Sjögren's syndrome. Cancer. 1992;69:1347-1355.

8 . 稲垣 宏, 栄本忠昭, 中村栄男. 胸腺 MALT リンパ腫. 病理と臨床 . 2002;20:602-607.

9 . Nakagawa A, Nakamura S, Koshikawa T, et al. Clinicopathologic study of primary mediastinal non-lymphoblastic non-Hodgkin's lymphomas among the J apanese. Acta Pathol J pn. 1993;43:44-54. 